DOI: 10.47745/ERJOG.2020.02.01

\title{
CSERNUS-LUKÁCS SZILVESZTER
}

\section{Nemzetek vagy nemzetiségek? Törvények és törvénytervezetek a nemzetiségi egyenjogúságról az 1860-as években*}

\author{
Nations or Nationalities? Acts and Bills on the Equality of Nationalities in the 1860s
}

Abstract: Apart from the relation between the Lands of the Crown of Saint Stephen and the other realms of the Habsburg Empire, the primary issue of the 1860s Hungary and Transylvania to handle was the nationality equality - accordingly, the recognitions of a nation and the language policy. As soon as the national question came into view, both the Hungarian and non-Hungarian political élites formulated their outlines on how to adjust regulations, intended to be epoch-making, regarding the national and language affairs, while the emperor temporarily coordinated the case with royal decrees until the definitive Nationality Act of 1868. The Act and its preceding drafts administered many domains regarding all branches of power, with the special role of the declaration of nations, namely the recognition of such as a legal entity, a juridicial person, which would (have) allow(ed) further entitled rights, deriving from a declaration in the era. The Hungarian and non-Hungarian acts and drafts examined in the study show decisive discrepancies regarding the number of nation(alitie)s recognized as legal entities, how the minorities were defined, and what concept of a nation each draft laid down. In my study, I examine the dissimilarities of the 5 draft plans (and the Act) made by the Hungarian élite, 8 draft plans (and acts of the 1863-1864 national assembly of Transylvania) related to the nationality political élite, draft plans and royal decrees associated to the emperor and the Royal Hungarian Lieutenancy, and a joint independence opposition - nationality draft plan.

Keywords: nationality question, language policy, 1863-1864 national assembly of Transylvania, Nationality Act, drafts, national recognition.

Összefoglaló: Az 1860-as évek Magyarországán és Erdélyében a közjogi viszony rendezése után a nemzetiségi egyenjogúság és így a nemzetkénti elismerések és a nyelvhasználat kérdése a legfontosabb megoldásra váró feladat volt. A nemzeti kérdés előtérbe kerülésével a magyar mellett a nemzetiségi politikai elitek is megfogalmazták tervezeteiket a nemzetiségi és nyelvi viszonyok korszakalkotónak szánt szabályozására, míg az uralkodó, ideiglenesnek szánt királyi rendeletekkel koordinálta a kérdést a végleges 1868. évi XLIV. törvénycikkig. A nemzetiségi egyenjogúságról szóló törvény és az azt megelőző tervezetek számos nyelvhasználati tárgykört szabályoztak mindegyik hatalmi ágat illetően; kiemelt szerepet kapott viszont a nemzeti deklarációk, azaz egyes közösségek kollektívumként, jogalanyként való elismerésének

* A tanulmány az Innovációs és Technológiai Minisztérium ÚNKP-19-3-SZTE kódszámú Új Nemzeti Kiválóság Programjának szakmai támogatásával készült. 


\section{ERDÉLYI JOGÉLET}

a kérdése, amely további, azt megillető jogosultságok levezetését tette (volna) lehetővé a korszakban. A tanulmányban vizsgált törvények és magyar, illetve nemzetiségi részről megfogalmazott törvényjavaslatok között meghatározó eltérések mutatkoznak a tekintetben, hogy hány nemzetet ismert el kollektívumként, hogyan definiálta a kisebbségeket, és milyen nemzetfogalmat állapított meg az adott tervezet. A tanulmányban ezek különbözőségét vizsgálom a magyar politikai elithez kötődő 5 törvénytervezeten (köztük a törvénycikken), 8 nemzetiségek által beterjesztett javaslaton (köztük az 1863-1864-es erdélyi országgyülés törvényein), az uralkodó és a Helytartótanács által jegyzett királyi rendeleteken és törvénytervezeteken és egy közös függetlenségi-nemzetiségi törvénytervezeten keresztül.

Kulcsszavak: nemzetiségi kérdés, nyelvpolitika, 1863-1864-es erdélyi országgyülés, nemzetiségi törvény, törvényjavaslatok, nemzetként való elismerés.

\section{A nemzetiségi és nyelvi törvényalkotás útvesztöi}

A XIX. század nemzetiségi törvényei és törvényjavaslatai zömében elsődleges szabályozási tárgykörként szerepelt a nemzetként való elismerés kérdése. A korszak nemzetiségi csoportjait érintő és nyelvhasználati tárgyú jogalkotását többféleképpen vizsgálhatjuk, mióta a reformkor nyelvtörvényei kinyitották a nemzetiségi és nyelvi kérdés Pandóra szelencéjét, hogy aztán az 1868-as nemzetiségi törvénnyel befejezettnek tekintsék a művet a honatyák. 1848-1849 tapasztalatait követően az uralkodó, I. Ferenc József és a magyar politikai elit számára világossá vált, hogy átfogó, tartós megoldást kell keresni az ország lakosságának több mint felét kitevő nem magyar ajkúak nyelvhasználati és nemzetiségi érdekei tárgyában. Az idő megérett arra, hogy az érintett nemzetiségi közösségek is megfogalmazzák javaslataikat, és nem csak egy nemzetiségi csoportra vonatkozóan, hanem kódexszerűen kínáljanak megoldást egész Magyarország nemzeti és nyelvi viszonyainak szabályozására.

A történeti szakirodalomban kiváló munkák születtek a nemzetiségi törvény koncepciójáról, a nézetek ütközéséről, ugyanakkor az előzmények feltárásakor csupán az 1861-es és 1867-es év magyar, illetve nemzetiségi törvényjavaslatai esnek vizsgálat alá, az 1868. évi XLIV. törvénycikk összevetésével kiegészülve. Szükségesnek tartom az összevetést nemcsak a 4 törvényjavaslat és maga a törvénycikk, hanem erdélyi exkurzus révén térben és a nemzetiségi törvényt követő törvényjavaslatok vizsgálata révén időben is kibővíteni. A szervezetileg is (az országgyülésen kívüli tervezetek bevonásával) kibővített vizsgálódás összesen tizenhét dokumentum összehasonlítását teszi lehetővé. A nemzetiségi és nyelvkérdés megoldására irányuló tervezetek két hullámban, 1861-1863-ban és 1867-1868-ban születtek, ebből a szempontból is külön kezelendő az erdélyi országgyűlés 1863-1864-es törvényhozási munkája. A törekvéseket többféleképpen csoportosíthatjuk: beszélhetünk törvénycikkekről, ${ }^{1}$ törvényjavaslatokról és javaslattervekről. A kihirdetett törvénycikk elsőségét a fontossági sorrendben nem kell

1 Ideszámítva a királyi rendeleteket is, amelyek Magyarországon 1860-tól 1868-ig, Erdélyben pedig 1860-tól 1865-ig meghatározták az állam, a közélet (közigazgatás, igazságszolgáltatás, oktatásügy) nyelvhasználatát. A nemzetként való elismerés kérdéskörét azonban nem érintették. 
Nemzetek vagy nemzetiségek? Törvények és törvénytervezetek a nemzetiségi egyenjogúságról...

különösebben indokolni, hiszen ez vált - a nemzetiségi törvény esetében évtizedekre normává; az 1864-es erdélyi, a román nemzet elismeréséről szóló törvénycikk és a - már Erdéllyel egyesített - magyarországi 1868. évi XLIV. törvénycikk tartozik ezen kategóriába. A törvényjavaslatokat illetően az 1861-es pesti országgyűlés képviselőházának nemzetiségügyi bizottsága által elkészített törvényjavaslatot és az ún. Vlad-Popoviciu-féle kisebbségi törvényjavaslatot vizsgálhatjuk az 1867-ben kidolgozott ún. albizottsági és az arra épülő bizottsági javaslat, a nemzetiségek legkiforrottabb álláspontját tükröző 1867es ún. kisebbségi törvényjavaslat, valamint Deák Ferenc 1868-as törvényjavaslata mellett. Az 1863-1864-es erdélyi országgyủléshez eljuttatott örmény nemzeti törvényjavaslat egy eddig nem vizsgált nemzetiségi csoport törekvéseinek bemutatására is alkalmat ad. Az 1861-es karlócai szerb kongresszus és a turócszentmártoni szlovák nemzeti gyülekezet határozatai mellett a helytartótanács 1863-as felírási javaslata sem volt formailag törvényjavaslat, de azt a célt szolgálta, hogy országgyủlési elfogadása esetén tartósan szabályozza a nemzetiségi viszonyokat. Egy rutén esperes 1867-es memorandumát azért érdemes a törvényjavaslatok körében vizsgálni, mert az országgyủlés nemzetiségi bizottsága is jelentésének mellékletei közé vette. Az 1870-ben a sajtóban megjelent két tervezet, bár törvényjavaslat formáját öltötte, sohasem került az országgyülés elé, mégis alkalmas arra, hogy a függetlenségi ellenzék álláspontját is vizsgáljuk, másrészt, mivel a nemzetiségi törvény hatálybalépése után kívántak alternatívát nyújtani, az 1868. évi XLIV. törvénycikk módosítási kísérletének tekinthetők.

A törvényjavaslatok vizsgálata, a négy nem magyar nemzetiséghez köthető, Király-hágón inneni tervezet és a rövid életű erdélyi román nemzeti, illetve nyelvtörvény elsősorban nemzetiségi oldalról ad választ arra, hogyan kívánták kezelni az ország lakosságának több mint a felét kitevő nem magyar ajkú népesség politizáló elitjei a nemzeti(ségi) és nyelvhasználati viszonyokat Magyarországon. Az 1865-1868-as országgyủlés magyar, azon belül kormánypárti többsége nyomán a kiegyezés után a kérdés valójában már az volt, hogy mennyit hajlandó a magyar politikai vezetés átvenni a nemzetiségi csoportok állásfoglalásainak tekinthető törvényjavaslatokból és egyéb tervezetekből.

Célom így nem elsősorban a nemzetiségi kiegyezési kísérlet értékelése, $\mathrm{s}$ nem is az 1868 előtti és az 1868-ban törvénybe iktatott nyelvhasználati szabályozási keret öszszehasonlítása. ${ }^{2}$ Az alábbiakban elsőként a nyelvi és nemzeti(ségi) viszonyokat érintő törvényjavaslatok és törvényjavaslatnak szánt tervezetek létrejöttét ismertetem, először magyar, majd nem magyar részről időrendi sorrendben az 1868-as törvénnyel és annak utóéletével zárva, melyek elemzése után vizsgálhatjuk azok tartalmát. A fent említett számos szabályozási terület közül ${ }^{3}$ azonban e tanulmány terjedelmi korlátaira való

2 Az 1860-as évek nyelvrendeleteiről (királyi leiratok formájában) lásd CSERNus-LukÁcs Szilveszter, A nemzetiségi és nyelvi kérdés szabályozása Magyarországon és Erdélyben az októberi diplomától a nemzetiségi törvényig. In: NAGY Noémi (szerk.): Nemzetiségi-nyelvi szuverenitás a hosszú 19. században, Gondolat, Budapest, 2020. 66-99, https://mtajogtortenet.elte.hu/media/47/20/55e535b1347b5708b2836 99b5197e3616050a78c43d7 2a2361f6a87e03f3/J\%C3\%89_46.pdf (letöltés ideje: 2020. 06. 30.).

3 A törvényhatóságok és községek nyelvi szabályozásáról a törvényjavaslatokban, javaslattervezetekben és az 1868-as nemzetiségi törvényben lásd: CSERnus-LukÁcs Szilveszter: Utak a nemzetiségi törvénycikkig, Tavaszi Szél konferencia kötete, Doktoranduszok Országos Szövetsége, Budapest, 2016, 363-374, http://www.dosz.hu/__doc/dokumentumfile/TSZ_I_kotet_161114_574o. pdf (letöltés ideje: 2020. 03. 20.). 
figyelemmel csak a nemzetként való elismerés, így a politikai nemzet kérdéskörét és a nemzetekre vagy nemzetiségi csoportokra mint kollektív jogalanyokra vonatkozó rendelkezéseket mutatom be.

\section{Törvényalkotási kísérletek magyar részröl}

A nemzetiségi és nyelvkérdés 1848-1849-es tapasztalatok utáni evolúciója több irányba indult el. A magyar(országi) politikai elitnek a neoabszolutizmus évtizede után az 1861-es országgyủlés nyújtott lehetőséget arra, hogy szabályozza a nemzeti(ségi) és nyelvi viszonyokat, amelyekről addigra ideiglenes jelleggel királyi rendeletek rendelkeztek. A munkáját 1861. áprilisban megkezdő országgyűlés elsődleges feladatának az uralkodóval és annak többi államával való viszony rendezését tekintette, de azzal párhuzamosan a nemzetiségi kérdés „magyar szakértőjének”, az 1848-as vallás- és közoktatásügyi miniszternek, báró Eötvös Józsefnek az indítványára a Ház egy 27 tagú országgyủlési bizottságot választott, hogy kidolgozza a nemzetiségi kérdést tartósan szabályozó törvényjavaslatot. A „nemzetiségi bizottmány”-ba fele részben nem magyar képviselőket választott a Ház, mintegy a kompromisszumra való hajlandóság jeleként. ${ }^{4}$ Már a bizottmány munkálatai közepette az országgyủléshez intézett július 21-i leiratában sürgette maga az uralkodó is a nemzetiségi viszonyokat rendező törvény megalkotását, fenntartva magának a jogot a „szerbek nemzeti érdekeinek biztosítása” tárgyában törvényjavaslatot juttatni a Ház elé, ${ }^{5}$ mintegy jelezve, hogy a Szerb Vajdaság és Temesi Bánság megszüntetése ellenére nem hagyta magára a szerb nemzetet. A testület tudomásul vette a turócszentmártoni szlovák „értekezlet memorandumát”, melyet az ülésvezető Tisza Kálmán a Háznak is bemutatott a bizottmánynak való továbbítás előtt, ${ }^{6}$ mely bizottmány augusztusra elkészítette törvényjavaslatát, az 1860-as évek első magyar törvényjavaslatát a nemzetiségi és nyelvkérdés tárgyában.7 A javaslat napirendre vételére, bár az bekerült a Ház

4 Demeter M. Attila: Politikai nemzet versus nemzetiség - 1848, 1861, $1868=$ Nemzet, faj, kultúra. A hosszú 19. században Magyarországon és Európában, szerk. HöRcHer Ferenc, LAJTAI László, MESTER Béla, Budapest, 2016, 245.

5 Mıкó Imre: Nemzetiségi jog és nemzetiségi politika, Minerva, Kolozsvár, 1944, 104.; Képviselőházi irományok, Pest, 1861, I. kötet, 44. sz., 170-178, https://library.hungaricana.hu/hu/view/ OGYK_KI-1861_01/?pg =0\&layout=s (letöltés ideje: 2020. 02.10.); DєÁK Ágnes: Az 1868-as nemzetiségi törvény ausztriai előzményei, Magyar Kisebbség, 2009/1-2, 29. A Szerb Vajdaság és Temesi Bánságot létrehozó 1849. november 18-i császári pátens már „elismerte” a „szerb nemzetet”; GRosschmid Gábor: A szerb vajdaság (1849-1860) = Bács-Bodrog vármegye egyetemes monográfiája. I. kötet, szerk. DudÁs Gyula, Bács-Bodrog vm. közönsége, Zombor, 1896, 553-607.

6 Képviselőház, LIII. ülés, 1861. 06. 27., Képviselőházi Napló, Pest, 1861, II. kötet, 224., https:// library.hungaricana.hu/hu/view/OGYK_KN-1861_02/?pg=0\&layout=s (letöltés ideje: 2020. 04. 20.)

7 Jelentése a nemzetiségi kérdés tárgyában kiküldött bizottmánynak. 1861. 08. 01., Képviselőházi irományok, 1861, I. kötet, 48. sz., 211-219. A nemzetiségi kérdésről 1860-1861-ben lásd Arató Endre: A magyar politikai nemzet fogalmának vitája az 1860-as évek országgyülése, Történelmi Szemle, 13/1, 444-448., http://real-j.mtak.hu/5711/1/TortenelmiSzemle_1970.pdf (letöltés ideje: 2020. 03. 20.); DєÁк Ágnes: „Nemzeti egyenjogúsitás”. Kormányzati nemzetiségpolitika Magyarországon 
Nemzetek vagy nemzetiségek? Törvények és törvénytervezetek a nemzetiségi egyenjogúságról...

irományai közé és a vitákban is szóba jött, az országgyủlés augusztus végi feloszlatása miatt már nem került sor. ${ }^{8}$ Az 1861-es országgyủlés utolsó előtti ülésnapján a Ház elfogadott egy Tisza Kálmán által beterjesztett határozatot (amely így csak az országgyülést magát kötelezte), miszerint amint az erdélyi képviselőkkel is kiegészült országgyülése lesz a hazának, parlamentnek felelős kormánnyal, az országgyűlés „első és legfontosabb teendői közé sorolja (...) nemzetiségek... bármely igényeinek" kielégítését (az ország politikai integritásával összeegyeztetve és a feliratokban kifejtett elveknek megfelelően). ${ }^{9}$

Az 1861 és 1865 közötti parlament nélküli időszak sem telt el nemzetiségi törvényjavaslat(-tervezet) nélkül. 1862 nyarán Arad vármegyei román értelmiségiek panaszszal éltek községi nyelvhasználati jogaikat illetően, melyre válaszul az uralkodó egy újabb nyelvrendelette ${ }^{10}$ és egy kancellári utasítással válaszolt, amelyben nemzetiségi törvényjavaslat kidolgozására utasította gróf Forgách Antal magyar kancellárt. A terv az volt, hogy az elkészült tervezetet majd mint törvényjavaslat juttassa az uralkodó a legközelebbi országgyűlés elé. A kancellár Bécsből utasította a Magyar Királyi Helytartótanács elnökét, Pálffy Móric gróf helytartót egy ezt előkészitő bizottmány létrehozására a helytartótanácson belül. A bizottmányba az uralkodói utasításnak megfelelően külső tagokat is bevontak, így 11 helytartótanácsi hivatalnok és 3 „civil” tárgyalt a javaslatról. Az elnök, Pálffy helytartó szem előtt tartotta a nem magyar képviseletet is a bizottmányban: 9 magyar mellett 2-2 román és rutén, illetve 1-1 szerb és szlovák alkotta a testületet, a nem magyar tagok felét a Helytartótanács berkeiből, felét a már említett külső tagokként delegálta a helytartó. ${ }^{11} \mathrm{~A}$ bizottság működéséről csak kevés részletes információ áll rendelkezésre, jegyzőkönyveiből mindenesetre kitűnik, hogy a bizottság asztalán ott voltak az 1861-ben született törvényjavaslatok és tervezetek: a karlócai szerb nemzeti kongresszus és a turócszentmártoni szlovák gyủlés határozatai, az országgyủlés nemzetiségi bizottmányának törvényjavaslata és a Vlad-Popoviciu-féle törvényjavaslat is. Abonyi

1849-1860, Osiris Kiadó, Budapest, 2000, 313-331.; MALFÉR Stefan: „Empfangen, nicht verstanden” (Überlegungen zur Nationalitätenfrage und zu einem Nationalitätengesetz für Ungarn in der Zeit des Provisoriums) $=$ Polgárosodás Közép-Európában -Verbürgerlichung in Mitteleuropa, szerk. SoмоGYI Éva, Budapest, 1991, 169-180.

8 A Ház valóban csak három rövid ülést tartott a javaslat elkészülte és a feloszlatás között, ahol bár bemutatták az országgyủléshez a karlócai szerb nemzeti kongresszus Újvidék város felterjesztéseként beérkező határozatait, csak a felirat sorsáról tárgyaltak és némely felvidéki, illetve délmagyarországi község és törvényhatóság országgyủléshez intézett irata került napirendre, melyben elhatárolódtak a turócszentmártoni gyủlés, illetve a karlócai kongresszus határozataitól. Ezek mellett Deák Ferenc már ekkor az országgyủlés várható feloszlatásáról beszélt. Ugyanakkor figyelembe kell vennünk azt is, hogy az 1865-1868-as országgyủlésen is közel egy évig „porosodott” a két később napirendre került nemzetiségi törvényjavaslat. Az 1849-es lendület már sehol sem volt. A Képviselőház LXV., LXVI. és LXVII. ülése, 1861. 08. 12., 21. Képviselőházi Napló, Pest, 1861. II. kötet, 285-283.

9 Képviselőház LXVII. ülés, 1861. 08. 21.; Képviselőházi Napló, 1861, II. kötet, 292.; Határozati inditvány, 1861. 08. 21.; Képviselőházi irományok, 1861, I. kötet, 53. sz., 277.

10 Ez volt az 1862. július 27-i királyi rendelet, amely részletesen szabályozta a községi nyelv megállapításának módját.

11 Köztük volt az 1848-1849-es szlovák felkelésben és az 1861-es turócszentmártoni gyűlésen jelentős szerepet játszó Ján Francisci és a cári inváziós haderők mellett szolgálatot teljesítő Adolf Dobrzánszky, a rutén nemzeti mozgalom harcias képviselője, valamint Teodor Mandić, az 1861-es karlócai szerb kongresszus jegyzője. 
István helytartótanácsos előadó aláírásával, 1862. október 25-i keltezéssel született egy uralkodónak szóló bevezető rész és két törvényjavaslat-változat. A bizottság álláspontja szerint a felirat megfelelt az 1861-es két törvényjavaslatban foglalt irányoknak, azonban részletes tárgyalását félbehagyta a bizottság, így nem tudunk arról, hogy bármelyik törvényjavaslat-változatot a maga teljességében elfogadta volna, de az ezen tanulmány szempontjából releváns politikai nemzet tételét és a nemzetiségi csoportokkal kapcsolatos fogalomhasználatot a preambulumnak tekinthető, uralkodónak szóló bevezető rész és a részletes vita alapjául elfogadott rövid változat tartalmazta. ${ }^{12}$

A javaslat nem érte el célját, a tervezet nemhogy nem került az 1865-ben összeülő országgyűlés napirendjére, de a tagokra rótt titoktartási kötelezettség miatt ismertté sem vált, a Helytartótanács irattárában lapult. Ugyanakkor a dokumentum képet ad a Schmerling-provizórium konzervatív magyar hivatali elitjének a nemzetiségi egyenjogúság kérdésben elfoglalt álláspontjáról.

Az 1865 decemberében újra összehívott országgyủlés képviselőháza 1866. április 26-28-án megalakította a 40 tagú „,nemzetiségi ügyben kiküldendő bizottságát”, ${ }^{13}$ melyben 6 román, 3 szerb és 2 német képviselő is helyet kapott. ${ }^{14}$ Mire a nemzetiségi bizottság berkeiből a javaslat kidolgozására megbízott 5 tagú albizottság vagy „alválasztmány” 15 1867 júniusára elkészítette törvényjavaslatát, már készen állt a benyújtásra a 26 fôs „nemzetiségi klub” törvényjavaslata is ugyanazon tárgyban, melynek tárgyalására később kerítünk sort. Az alválasztmány „lelkiismeretesen felhasználta, illetve figyelembe vette” 1861-es „elődei” és kortársai munkáit, ugyanis vizsgálta és saját javaslatához mellékletként csatolta az 1861-es év nemzetiségi bizottmányi törvényjavaslatát, a VladPopoviciu-féle törvényjavaslatot, a karlócai szerb nemzeti kongresszus határozatait és a turócszentmártoni szlovák memorandumot, ezek mellett Bukovszky György rutén

12 DeÁK Ágnes: Soknemzetiségü nemzetállam és soknemzetiségü birodalom erôterében - Nemzetiségpolitikai alternatívák 1868 előtt, Századvég, 2008/4, 51-77, 53-54. A törvényjavaslat kidolgozására szóló felhívást lásd Pálffy levélfogalmazványa a fökancellárnak, 1862. 08. 19, Magyar Nemzeti Levéltár/Országos Levéltár/ Abszolutizmus kori levéltár, D 191 M. Kir. Helytartótanács, elnöki iratok 16823.III.1862. A törvényjavaslatok szövegét ld.: Abonyi István m. k. helyt. tanácsos mint előadó által szerkesztett felírási és törvényjavaslat a nemzetiségi és nyelvi jogviszonyok tárgyában, 1862. okt. 25. MNL/OL/Abszolutizmus kori levéltár, D 191 M. Kir. Httanács., eln. iratok 16823. III. 1862. A törvényjavaslat kidolgozására összehivott bizottmány ülésének jegyzőkönyve, MNL/OL/D 215 II. 1863:24, 326. A helytartótanácsi törvényjavaslat elemzését l. CsERnUs-LuKÁcs Szilveszter: Felírási javaslat a nemzetiségi egyenjogúság tárgyában, Századok, 2017/1, 189-200.

13 Az 1861-es és az 1866-1868-as bizottságokat illetően a szóhasználat különbsége (a teljes tartalmi és fogalmi egyezés ellenére) alkalmat ad arra, hogy az 1861-es bizottságot „,bizottmánynak”, míg az 1866-1868-ast egyszerủen „bizottságnak” nevezzük.

14 Képviselőház, LV. ülés, 1866. 03. 28, Képviselőházi Napló, Pest, 1865, II. kötet, 28, 84, https:// library.hungaricana.hu/hu/view/OGYK_KN-1865_02/?pg=0\&layout=s (letöltés ideje: 2020. 03. 20.) Jelentése a nemzetiségi kérdés tárgyában kiküldött bizottságnak, 1868. 03. 30. Képviselőházi irományok, Pest, 1865, IV. kötet, 200. sz., 79. https://library.hungaricana.hu/hu/view/OGYK_KI1865_04/?pg=0\&layout=s (letöltés ideje: 2018. 03. 20.).

15 Sipos Levente (szerk.): A magyar állam és a nemzetiségek. A magyarországi nemzetiségi kérdés történetének jogforrásai 1848-1993, Napvilág Kiadó, Budapest, 2002, 58. 
Nemzetek vagy nemzetiségek? Törvények és törvénytervezetek a nemzetiségi egyenjogúságról...

esperes 1867-es tervezetét és a 26 nemzetiségi képviselő említett törvényjavaslatát. ${ }^{16}$ Az albizottság javaslatát a nemzetiségi bizottság mellett a Ház is megismerhette. ${ }^{17} \mathrm{Az}$ alválasztmányi törvényjavaslaton a 24 fősre apadt nemzetiségi bizottság 11 magyar, 3 román és 1-1 szerb és német taggal való 1868. áprilisi „feltöltése” után módosításokat tettek, azok azonban e tanulmány fő kérdését nem érintették. ${ }^{18} \mathrm{~A}$ várva várt történelmi pillanat, amikor a nemzetiségi törvényjavaslatok vitáját a magyar országgyűlés napirendjére vette, 1868. november végén, a parlament feloszlása előtt alig három héttel jött el. ${ }^{19} \mathrm{~A}$ hosszú idő alatt elkészült (immár mellékletek nélküli) nemzetiségi bizottsági törvényjavaslat végül nem állta ki a ,jobb alternatíva” próbáját: a november végi szavazáson a Képviselőházban - az időközben Deák Ferenc által előterjesztett változattal szemben - egyetlen szavazatot sem kapott. ${ }^{20}$

\section{Kísérletek nemzetiségi és nyelvtörvény megalkotására - nem magyar részröl}

A nem magyar nemzeti mozgalmak által készített tervezeteket megkülönböztethetjük aszerint, hogy azok az egyes nemzetiségi csoportok saját igényeinek kielégítéséről szóltak-e, avagy Magyarország minden nemzetiségére és nyelvére nézve tartalmaztak-e egységes szabályozásjavaslatot. Az 1861. április 2-án, a pesti országgyűléssel egy időben megnyílt szerb nemzeti kongresszus határozata ${ }^{21}$ az előbbi kategóriába tartozik. Bár Karlóca a Katonai Határőrvidék területéhez tartozott, de a kongresszusra a horvátországi Szerémség mellett Bács-Bodrog vármegyéből és a Bánságból választott képviselők is részt vettek. Az uralkodó által engedélyezett kongresszus célja az volt, hogy határozatot hozzon a szerbek követeléseiről, amelyet az uralkodó elé terjesztenek,

16 Jelentése az 1865-dik évi magyar országgyűlés képviselőháza által a nemzetiségi kérdés tárgyában kiküldött bizottság alválasztmányának, 1867. 06. 25. Képviselőházi irományok, Pest, 1865, II. kötet, 133. sz., 251-276, https://library.hungaricana.hu/hu/view/OGYK_KI1865_02/?pg=0\&layout=s (letöltés ideje: 2020. 03. 20.).

17 Képviselőház, CXLVI. ülés, 1867. 06. 26., Képviselőházi napló, Pest, 1865, IV. kötet, 310-311, https://library.hungaricana.hu/hu/view/OGYK_KN-1865_04/?pg=0\&layout=s (letöltés ideje: 2020. 03. 04.).

18 A központi bizottság jelentése a nemzetiségi egyenjogúság tárgyában szóló törvényjavaslatról. Képviselőházi irományok, Pest, 1865, VI. kötet, 361. sz., 249-253, https://library.hungaricana. hu/hu/view/OGYK_KI-1865_06/?pg=0\&layout=s (letöltés ideje: 2020. 03. 20.). Az új tagok nemzetiségi hovatartozásáról l. KEMÉNY G. Gábor: Iratok a nemzetiségi kérdés történetéhez Magyarországon a dualizmus korában, I. kötet, 1867-1892, Tankönyvkiadó, Budapest, 1952, 80.

19 Képviselőház, CCXI., CCXII. ülések, 1868. 04. 03, 4, Képviselőházi Napló, Pest, 1865, VII. kötet, 62-71, https://library.hungaricana.hu/hu/view/OGYK_KN-1865_07/?pg=0\&layout=s (letöltés ideje: 2020. 03. 30.)., Мıко́: i. m., 125.

20 Képviselőház, CCCXXVII. ülés, 1868. 11. 28, Képviselőházi Napló, Pest, 1865, XI. kötet, 170., https://library.hungaricana.hu/hu/view/OGYK_KN-1865_11/?pg=0\&layout=s (letöltés ideje: 2020. 03. 30.).

21 L. 16. lábjegyzet. 
hogy ő azt törvényjavaslatként az országgyủlésnek benyújtsa. Végül a határozat (magyar nyelvü fordításban) - ahogy arról már szó esett - mint Újvidék város felirata került az országgyűlés elé, s azt mind az 1862-1863-as helytartótanácsi bizottmány, mind pedig az 1866-1867-es országgyűlési nemzetiségi bizottság felhasználta.

A karlócai szerb kongresszussal párhuzamosan tárgyalja a szakirodalom a $t u$ rócszentmártoni szlovák gyülés határozatát, ${ }^{22}$ amelyet 17 szlovák értelmiségi, publicista aláírója 1861. június 7-i keltezéssel kívánt az országgyủlésnek eljuttatni. Az 1861-es országgyưlésben való bemutatása után az iratot annak nemzetiségi bizottmánya, az 1862-1863-as helytartótanácsi bizottmány és az 1866-1867-es képviselőházi nemzetiségi bizottsága is számontartotta annak ellenére, hogy számos felvidéki törvényhatóság és község már az 1861-es országgyűlés idején külön tiltakozó iratokat fogadott el. Az országgyülés feloszlatása után, 1861 decemberében egy szlovák küldöttség adta át az uralkodónak a turócszentmártoni memorandumot a szlovák sérelmek orvoslását kérve. ${ }^{23}$

A nem magyar politikusok nemcsak nemzeti gyủléseken, hanem az országgyủlésben is aktívan politizáltak. Kettejük, Sigismund Popoviciu és Aloisiu Vlad 1861. július 20-ra készítette el az első nem magyar nemzetiségi törvénytervezetet, ami már formáját tekintve is törvényjavaslat volt és Magyarország egészére vonatkozott. Az Arad, illetve Krassó vármegyékben megválasztott képviselők a nemzetiségi bizottmány tagjai voltak, javaslatukat a bizottmányi munka alternatívájának szánták, ám annak megtárgyalására szintén nem került sor. ${ }^{24}$

Az erdélyi törvényalkotás eddig kívül esett a szakirodalom látókörén a magyarországi nyelvtörvények tárgyalásakor, amit indokol, hogy az Erdélyre vonatkozó törvénycikkek nem vonatkozhattak Magyarországra, ami fordítva is igaz volt egészen az 1868-as nemzetiségi törvénycikkig. Az uralkodó 1863 júliusára hívta össze az erdélyi országgyűlést Nagyszebenbe; az összehívó leiratban első helyen szólította föl az országgyủlést a román nemzet és vallásai, valamint a három erdélyi nyelv egyenjogúsitása tárgyábani törvények megalkotására ${ }^{25} \mathrm{~A}$ törvényhozás $37 \%$-ban román, $35 \%$-ban magyar és $28 \%$-ban szász képviselőből és az uralkodó által kinevezett regalista honatyákból állt. A magyar képviselők (és a regalisták többsége) azonban bojkottálták az országgyủlés munkáját, az országgyủlésnek így csak 7\%-a maradt magyar, mind királyi tisztviselők, amit aligha lehetett a közvélemény előtt a magyar közösség képviseletének tekinteni. ${ }^{26}$

A „csonka” erdélyi országgyűlés elé a nemzetként való elismerést illetően két témában került törvényjavaslat: a román és az örmény nemzet elismerésére vonatkozóan.

22 L. 16. lábjegyzet.

23 Berzeviczy Albert: Az absolutizmus kora Magyarországon: 1849-1865, III. kötet, Franklin Társulat, Budapest, 1922, 410, http://real-eod.mtak.hu/8790/ (letöltés ideje: 2020. 03. 04.).

24 Jelentése a nemzetiségi kérdés tárgyában kiküldött bizottmánynak (melléklet). Képviselőházi irományok, 1861, I. kötet, 48. sz., 215-219.

25 Mester Miklós: Az autonóm Erdély és a román nemzetiségi követelések az 1863-64. évi nagyszebeni országgyülésen, Dunántúl Pécsi Egyetemi Könyvkiadó, Budapest, 1936, 137.

26 A kormányzat négyszer írt ki új szavazást az érintett választókerületekben és neveztetett ki új regalistákat, a magyar szavazók kitartását azonban nem sikerült megtörni. SzÁsz Zoltán (szerk.): Erdély története három kötetben, Akadémiai Kiadó, Budapest, 1986, 1495-1497., https:// mek.oszk.hu/02100/02109/html/ (letöltés ideje: 2020. 03. 20.); Mester: i.m., 142. 
Nemzetek vagy nemzetiségek? Törvények és törvénytervezetek a nemzetiségi egyenjogúságról...

Előbbi törvényjavaslat kormány (királyi biztos) által ${ }^{27}$ előterjesztett változatán az 1 magyar és 7-7 román és szász tagból álló törvény-előkészítő bizottmány lényegében nem változtatott, ${ }^{28}$ az országgyủlés 1863 . augusztus 28 . és szeptember 7 . között vitázott róla, majd az uralkodói szentesítést a törvényjavaslat 1864. május 30-i kihirdetése, így hatálybalépése követte. ${ }^{29}$ A román nemzet elismerése azonban Erdély Trianon előtti köztörténetének rövid epizódja maradt: Ferenc József magyar királlyá koronázása után nem sokkal, 1867. június 20-án ugyanis a magyar miniszterelnök ellenjegyzésével kelt rendeletében hatályon kívül helyezte a nagyszebeni országgyűlés minden határozatát. ${ }^{30}$

Két román képviselő, az 1848-1849-es román felkelésben is részt vállalt Sigismund Borlea és már az 1863-1864-es nagyszebeni országgyủlésnek is tagja, Iosif Hodoșiu említették némely felszólalásukban a magyarországi parlamentben, hogy a nemzetiségi törvény megalkotása során figyelembe kell venni a nagyszebeni országgyülés alkotta törvénycikkeket is. ${ }^{31}$ Ezenkívül az is bizonyítja, hogy a nagyszebeni törvényhozás nem merült a feledés homályába, hanem a kiegyezést követő első években a román nemzeti(ségi) programok hivatkozási alapjaként szerepelt, hogy a balázsfalvi román értelmiség 1868. tavaszi „Pronunciamentuma” és az 1872-es gyulafehérvári román nemzeti gyủlés programja a nagyszebeni törvények újabb hatálybaléptetését követelték. ${ }^{32}$

27 Az 1863. évjúlius 1-re Nagy-Szebenbe egybehivott erdélyi országgyülés irományai, Nagyszeben, 1864, 44. sz., 144., https://library.hungaricana.hu/hu/view/Orszaggyules_ErdelyiOrszaggyDok_18621864_ Iromanyok/ ?pg=0\& layout=s (letöltés ideje: 2020.02 .10 .).

28 Mester: i. m., 159-162. A törvényjavaslatok szövegét l. A kormányzat gróf Nádasdy Ferenc erdélyi kancellár aláírásával beterjesztett 1863. szept. 28-i törvényjavaslata, Erdélyi országgyülési irományok, 45. sz., 145-149., https://library.hungaricana.hu/hu/view/Orszaggyules_ ErdelyiOrszaggyDok_18621864_Iromanyok/?pg=0\&layout=s (letöltés ideje: 2020. 03. 20.).; A bizottmány törvényjavaslata, Erdélyi országgyülési irományok, 26. sz., 67-68, Jegyzőkönyve az 1863-ik évi Sz. Jakab hó 1-ére Nagy-Szeben szabad királyi városába legfelsőbbleg egybehívott erdélyi országgyülésnek. Nagyszeben, 1864, 1863. 08. 26-i ülés, 68-69., https://library.hungaricana. $\mathrm{hu} / \mathrm{hu} /$ view/Orszaggyules_ErdelyiOrszaggyDok_1863-1864_Jkv/?pg=0\&layout=s (letöltés ideje: 2020. 04. 20.). A törvényjavaslatot l. még: Erdélyi országgyülési irományok, 21. sz., 45-46., jegyzőkönyvbe nem vétetett. Erdélyi országgyülési irományok, 29. sz., 74-75.; Erdélyi országgyülési jkv., 1863. 09. 07, 95, az országgyủlés előtt: erdélyi országgyủlés, 1863. 08. 01-i ülés, Erdélyi országgyülési jkv., 134-135; az uralkodóhoz első ízben (1863. 08. 07.) felterjesztett törvényjavaslat: Erdélyi országgyülési irományok, 53. sz., 159-161.; erdélyi országgyűlés, 1863. 08. 07-i ülés, Erdélyi országgyülési jkv., 141-147.

29 Erdélyi országgyủlés, 1863. 08. 28-09. 07-i ülések, Erdélyi országgyülési jkv., 71-96; Erdélyi országgyúlési irományok, 81. sz., 198-200; erdélyi országgyủlés, 1864. 05. 30-i ülés, Erdélyi országgyülési jkv., 172.

30 Leirat az erdélyi főkormányszékhez a nagyszebeni 1863/5-i tartománygyülés határozmányainak hatályon kivül tétele iránt. Magyarországi Törvények és Rendeletek Tára, 1867, Pest, 1868, https://library.hungaricana.hu/hu/view/OGYK_RT_1867/?pg=0\&layout=s (letöltés ideje: 2020. 03. 20.), 78. sz., 169-171.

31 Kemény: i. m., 13. Képviselőház XXX. ülés, 1866. 02. 23. Képviselőházi Napló, Pest, 1865, I. kötet, 313, https://library.hungaricana.hu/hu/view/OGYK_KN-1865_01/?pg=0\&layout=st (letöltés ideje: 2020. 03. 30.). Képviselőház CI. ülés, 1867.03.08, Képviselőházi Napló, Pest, 1865, III. kötet, 298, https://library.hungaricana.hu/hu/view/OGYK_KN-1865_03/?pg=0\&layout=s (letöltés ideje: 2020. 03. 30.). Hodoșiu 1867 után mondott beszédét l. Képviselőház CCLXXI. ülés, 1868. 07. 27, Képviselőházi Napló, Pest, 1865, IX. kötet, 276, https://library.hungaricana.hu/hu/view/ OGYK_KN-1865_09/?pg=0\&layout=s (letöltés ideje: 2020.03. 30.).

32 KeMÉNY: $i . m .83 ., 339$. 
Az örmény nemzet (és az örmény katolikus vallás) elismeréséről szóló törvényjavaslatot Lászlóffy Antal indítványozta az erdélyi országgyưlésen, amihez további tíz magyar, román és német honatya csatlakozott aláírásával. A bizottsághoz eljuttatott javaslat azonban nem került az országgyülés napirendjére. ${ }^{33}$

Az 1863-1864-es nagyszebeni országgyưlés volt az első és utolsó alkalom a korszakban, hogy a törvényalkotásban nem magyar nemzeti mozgalmak programja dominált (természetesen az uralkodói akarat mellett), a magyarországi országgyưléseken kisebbségi helyzetből való politizálásra jutott tér számukra. Az 1865-1868-as pesti országgyưlés nemzetiségi bizottságának munkájával párhuzamosan 17 román, 8 szerb és 1 rutén, összesen 26 képviselő kvázi „árnyékbizottságként” már 1867 februárjára kidolgozta törvényjavaslatát, melyet a nemzetiségi bizottság albizottsága mellékletként felvett „törvényjavaslat-gyüjteményébe”. ${ }^{34}$ Az úgynevezett kisebbségi törvényjavaslat vitáját így a képviselőház a bizottság és Deák Ferenc egyéni törvényjavaslatával egy időben vette napirendre 1868 novemberében. A kisebbségi javaslat 26 aláírója közül 3 a vita idején már nem volt a képviselőház tagja, 4-en nem vettek részt a szavazás ülésnapján, ${ }^{35}$ ketten, Hodoșiu és Vlad pedig nemmel szavaztak az általuk is jegyzett törvényjavaslatról. A 26 főből így csak 17-en adták voksukat a kisebbségi törvényjavaslatra, 7 további nem magyar nemzetiségű képviselővel egyetemben. ${ }^{36} \mathrm{Ez}$ a 24 szavazat túl kevésnek bizonyult a kisebbségi javaslat elfogadásához. ${ }^{37} \mathrm{~A}$ két prominens román képviselő nemmel szavazása rámutat arra, hogy nem feltétlenül volt egységes ez a „nemzetiségi klub” sem, nem beszélhetünk egyöntetüen kiforrott álláspontokról. Az 1861-es nemzetiségi bizottmány felét adó nemzetiségi képviselőket is sikerült akkor megnyerni egy olyan törvényjavaslat számára, amelyben az egy magyar politikai nemzet elvét fektették le, a nemzetiségek nemzetként való elismerése nélkül.

\section{Az 1868. évi XLIV. törvénycikk a nemzetiségi egyenjogúság tárgyában}

A Ház asztalán fekvő bizottsági törvényjavaslat Deák Ferenc személyében nem várt kihívóra talált. A „kiegyezés atyja” az utolsó pillanatban, az általános vita kezdetén nyújtotta be indítványát, amely javarészt a nemzetiségi bizottság törvényjavaslatán alapult:

33 Mester: i. m., 196-197. Erdélyi országgyülés, 1863.10. 09-i ülés, Erdélyi országgyülésijkv., 153. A törvényjavaslat szövegét 1. Erdélyi országgyülési irományok, 62. sz., 175-177.

34 Jelentése a nemzetiségi kérdés tárgyában kiküldött bizottság alválasztmányának [értsd: albizottság], 1867. 06. 25., Képviselőházi irományok, 1865, II. kötet, C melléklet a 133. számhoz, 271-274.

35 Mint Branovački István, Csernovics Péter és az 1848-1849-es szerb felkelés egyik katonai vezetője, a Vajdaság főodboraként ismertté vált Đorđe Stratimirović.

36 Közülük Elia Macellariu és Ioane Puscariu a nagyszebeni országgyülésnek is tagja volt. Erdélyi országgyủlés, 1863. 06. 15-i ülés, Erdélyi országgyülési jkv., 1-7.

37 A név szerinti szavazás eredményét l. Képviselőház, CCCXXXVI. ülés, 1868.12. 07, Képviselöházi napló, 1865, XI. kötet, 425. A szakirodalom egy része tévesen, feltehetően az igennel szavazók száma alapján, 24 nemzetiségi képviselő indítványaként hivatkozik a kisebbségi javaslatra. 
annak 31 paragrafusából 20-at meghagyott, 8-at és egy preambulumot pedig sajátjaként hozzátett. ${ }^{38} \mathrm{Az}$ általános vita végén egymás után szavaztak a három törvényjavaslatról: a nemzetiségi bizottmányét senki sem támogatta, a kisebbségi törvényjavaslatot 24 képviselő pártolta (5,93\%), 267 szavazott ellene (65,93\%), 113 távollévő $(27,9 \%)$ mellett. Ezen második szavazást követően a „szélső baloldali román képviselők” kivonultak a teremből, így Deák Ferenc törvényjavaslatának „,általános többség” általi elfogadásánál már nem voltak jelen. ${ }^{39}$

A részletes vitára november 29-én került sor, amely ülés elején Alexandru Mocioni, a kisebbségi törvényjavaslat társszerzője és Svetozar Miletić vezető szerb nemzeti mozgalmár több képviselőtársuk nevében kijelentették, hogy abban nem vesznek részt. A vita során a Ház a 28 paragrafusból kettőt kitörölt, hármat hozzáadott, míg hatot kisebb mértékben megváltoztatott. A Képviselőház december 1-jén fogadta el a végleges törvényjavaslatot, ${ }^{40}$ amelyet rövidebb vita után a förendiház is támogatott. A december 6-i királyi szentesítést másnap a törvénycikk országgyủlési kihirdetése követte. A jogszabály december 24-i hatálybalépésétől ${ }^{41}$ beszélhetünk a nyelvi és nemzetiségi viszonyok törvényi szintű szabályozásáról Magyarországon.

\section{Törvényjavaslatok 1868 után}

A nemzetiségi törvénycikk revíziója 1868 után nem került törvényjavaslat formájában napirendre a dualizmus első évtizedeiben, ahogy később sem. Két törvényjavaslatnak szánt tervezetet azonban ismerünk, amelyek azt célozták. A függetlenségi ellenzék és nemzetiségi politikusok közötti tárgyalások eredményeképpen született meg 1870 tavaszára egy „nemzetiségi törvényjavaslat”. A tárgyalásokon 4 függetlenségi ${ }^{42}$ képviselő vett részt, a nem magyar nemzeti mozgalmakat Miletić, Hodoșiu és Alexandru Mocioni képviselte. A tervezet pontjaiban többnyire az 1867-es kisebbségi törvényjavaslat rendelkezései köszönnek vissza. A dokumentumot idő előtt megjelentette a nemzetiségi sajtó, majd az ellenzéki $A$ Hon is közölte, a Ház elé törvényjavaslatként azonban végül nem került. ${ }^{43}$

38 Törvényjavaslat a nemzetiségi egyenjogúság tárgyában. 1868. 11. 24. Képviselőházi irományok, Pest, 1865, VII. kötet, 392. sz., 14-17., https://library.hungaricana.hu/hu/view/OGYK_KI1865_07/?pg=0\&layout=s (letöltés ideje: 2020 . 03. 20.).

39 Képviselőház, CCCXXVII. ülés, 1868.11.28. Képviselőházi napló, 1865, XI. kötet, 170.

40 A képviselőházi vitáról 1. ScHLETT István: A nemzetiségi törvényjavaslat országgyülési vitája 1868 , TTFK-Kortárs Kiadó, Budapest 2002.; PÉTER László: Az 1868:XLIV. tc. „a nemzetiségi egyenjogúság tárgyában"és a törvényhatóság hivatalos nyelve = Az Elbától keletre, szerk. PÉTER László, Osiris, Budapest, 1998.

41 1868. évi III. tc. a törvények kihirdetéséről. MÁRKus Dezső (szerk.): Magyar Törvénytár 10001890. 1836-1868. évi törvényczikkek - Corpus Juris Hungarici, VIII. kötet, Franklin Társulat, Budapest, 1896, 368. Az 1868. évi XLIV. tc. a nemzetiségi egyenjogúság tárgyában. Márkus: $i . m$., 490-494.

42 Köztük a pártelnök, Irányi Dániel és Madarász József.

43 KemÉny: i. m., 225-226. 
Ugyanezen évben az 1861-es turócszentmártoni gyülés egyik tagja, a szlovák publicista Viliam Pauliny Tóth véleményezés céljából „küldte” el baloldali ellenzéki kollégáinak a szlovák sajtóban megjelent közleményét „Törvényjavaslat a nemzetiségek egyenjoguvá tételéről” címmel. ${ }^{44}$

\section{A „mi" és „ök" elválasztása és kollektív jogok a tervezetekben és a nemzetiségi törvényekben}

A Magyarországon élők nemzeti/nemzetiségi alapú csoportokra osztásának törvényben való megnyilvánulását a nevezett közösségek beazonosítására szolgáló kortárs megnevezéseken érhetjük tetten. Jelentősége van annak is, hogy az adott törvény(javaslat) nevén nevezi-e a románokat, szerbeket stb., vagy csak általánosságban szól nemzetiségi csoportokról. Amennyiben már elismerést nyert egy nemzet/nemzetiség, a következő kérdés az azt megillető kollektív, azaz a nemzetiségi csoportot mint alanyt megillető jogosultságok tárgyköre, így ezen csoportok beazonosításán túl azt vizsgáljuk, milyen jogokat tulajdonítottak a tervezetek, törvényjavaslatok és törvények a nevezett nemzeteknek vagy nemzetiségeknek mint jogalanyoknak.

A „nemzet” fogalmát kétféleképpen, egyrészről önmagukra mint szerbekre használta az 1861-es karlócai határozat, másrészről jelzős szerkezetben (nemzeti jog, nemzeti szervezet). A „nemzetiség” fogalom ezzel szemben a tervezett Szerb Vajdaságban élő egyéb csoportok megjelöléseként szerepel a dokumentumban. A szerbeket megillető kollektív jogokként jelöli meg a határozat a Vajdaság autonóm terület felállítását, amely leginkább egy kibővített jogkörủ rendi törvényhatóságra, kiváltságolt kerületre hasonlított az irományban körülírtak szerint. Vajdaság minden részletszabálya így a szerb nemzet önigazgatási jogainak is tekinthető.

A turócszentmártoni gyűlés szóhasználatában a „nemzet” szó száznál is többször fordul elő, ennyit egyik vizsgált dokumentum sem tartalmaz. Magyarország összes nemzetiségi csoportját (azok felsorolása nélkül) nemzetként ismeri el a határozat, akiket nyelvük különböztet meg egymástól. A kollektív jogokat a nemzetként való elismerés velejárójának tekinti az irat, mondván, „egy nemzet nem eszményi lény, de tettleges valóság: nem elégséges... szellemi általánosságban elösmerni”; a szlovákok ezért területi autonómiával együtt kérik nemzetként való elismerésüket.

A Vlad-Popoviciu-féle törvényjavaslat a magyarországi nemzetiségek megjelölésére szinonimaként használja a „nemzetiséget”45 és a „külön nyelvü népeket”. Emellett az egész országra kiterjedő politikai nemzetet is definiál, amely azonban nem „magyar” jelzőt visel, hanem megnevezése: „Magyarország politikai nemzete”. Ezen politikai nemzet alapja az állampolgárság, amelynek nincs tituláris nemzete, nincs kulturális attribútuma. Ezzel együtt a nemzetként való elismerés kiterjed a „külön nyelvü népekre” is, melyek „nemzetként

44 Uo. 238-241.

45 Ahogy a dokumentum címe is Törvényjavaslat nemzetiségi ügyben. 
Nemzetek vagy nemzetiségek? Törvények és törvénytervezetek a nemzetiségi egyenjogúságról...

ismertetnek el". A törvényjavaslat kettős nemzetfogalom-használatának megértéséhez érdemes egyik beterjesztője, Vlad képviselőházi felszólalását segítségül hívni: „a politikai nemzetiség nem egyéb, mint egy polyglott országban éló különféle népiségek politikai s történeti múltjának, életének, s közös müködésének s érdekének diplomatikai kifejezése" - fejtegette. ${ }^{46}$ A politikai nemzet hat alkotóelemből, a felsorolt hat magyarországi nemzetből (magyar, román, szerb, rutén, szlovák és német) áll. Ezen nemzeteknek kollektív jogokat a Vlad-Popoviciu-féle törvényjavaslat nem ad az iskolaalapításon, azok felügyeletén, tudományos társulat- és alapítványalapítási jogokon, azaz a kulturális autonómia köréhez tartozó jogosultságokon túl. Ebbe többet belelátni legfeljebb azon az alapon lehetne, hogy a hat nemzet kollektívumként, jogok alanyaként való elismerése megnyitotta az utat további jogosultság garantálása felé, azaz „megtölhetővé” vált (volna). Területi-közigazgatási kérdésekben a Vlad-Popoviciu-javaslat a vármegyék nemzetiségi alapú „kikerekítésénél”, azaz a megyei határoknak az etnikai-nemzetiségi viszonyok szerinti korrekciójánál tovább nem ment.

Az Eötvöshöz kötött 1861-es nemzetiségi bizottmány törvényjavaslata már megkettőzte a „magyar” melléknév jelentését. Legfőbb kollektívumnak a „magyar állam históriai fogalmának megfelelö egységes és oszthatatlan magyar nemzetet" deklarálta. Ezen nemzetet az állampolgárok összessége (Magyarország „minden ajkú polgárai”) alkotja. Ezen belül ismeri a törvényjavaslat a „népeket” vagy „nemzetiségeket” is, név szerint a „magyar, szerb, szlovák, német, román, rutén, sat.” közösségeket, jelezve tehát azt is, hogy a kategória bővíthető. Ezen nemzetiségek kollektív jogaiként az iskolaalapítási és -fenntartási jogot ismeri el a törvényjavaslat, valamint a „nemzetiségek, mint testületek szabad egyesülés utáni kifejlődését”. A nemzetiségeket tehát az egyesülési szabadság keretei között véli jogi tekintetben „megalkothatónak” az „egyesek és testületek nemzetiségijogairól” címet viselő törvényjavaslat.

Az 1863-as helytartótanácsi bizottmány hosszabb ,javaslatverziója” szinte szó szerint átvette az 1861-es nemzetiségi bizottmány politikai nemzetfogalmát, miszerint Magyarországon csak egy nemzet, „a magyar állam historiai fogalmának s jogainak megfelelo egységes és oszthatatlan magyar politikai nemzet" létezik, amelyet a preambulum szerint a keresztény vallású állampolgárok alkotják. Emellett azonban azt is tartalmazza, hogy a „külön nyelvvel biró népfajokból kiálló nemzetiségek, jelesen magyarok, németek, szlávok, románok, rutének és szerbek, polgári s vallási tekintetben egyenjogú nemzetiségek". A törvényjavaslat rövidebb változata azonban már másképp fogalmaz, nem használja a „nemzet” fogalmat, mellőz bármiféle deklarációt magyar vagy magyarországi nemzetről, csak „a hazában lakó testvér nemzetiségek"-ről beszél. A felsorolt magyar, német, szlovák, román, rutén és szerb közösségeket tehát mindkét változat nemzetiségi kollektívumokként elismeri. A hosszabb változat a politikai nemzet alkotóelemeit tekintve a Vlad-Popoviciu-féle javaslatra emlékeztet azzal a markáns különbséggel persze, hogy „magyar nemzetről” szól, és azt itt nem „nemzetek”, csak „nemzetiségek” alkotják, köztük a magyar. Magyarnak lenni eszerint lehet a politikai nemzet tagjaként és az egyik nemzetiség tagjaként is. A magyarországi izraelitákat a politikai nemzetből kizáró rendelkezést azután a javaslat rövidebb verziójában a bizottmány a részletes vita során törölte. A nemzetiségeket mint

46 Képviselőház, XL. ülés, 1861. 06. 08, Képviselőházi napló, 1861, II. kötet, 89. 
csoportokat megillető jogokként a hosszabb és a rövidebb javaslat egyaránt az iskola- és a művelődési egyesület alapításának és müködtetésének jogát nevezi meg.

A „román nemzet és annak vallásai egyenjogúságának keresztülviteléről” szóló erdélyi törvénycikk a román nemzetként való elismerését deklarálta. Erdély többi megnevezett nemzetét (magyar, szász, székely) és a románt azonban a továbbiakban „nemzetiségként” is említi a törvény. A dokumentum látszólag az erdélyi rendi nemzetek sorába emeli a románokat („a négy nemzet... az erdélyi hazai alkotmány értelmében egyenlő politikai jogokkal bír"), holott ezen rendi különállásokat Erdélyben felszámolta az 1848-1849-es átalakulás. Így a románok rendi nemzetté válása már nem rendelkezhetett tartalommal, a modern nemzetként való elismeréséhez azonban a törvénycikk nem füzött konkrét kollektív jogokat, sőt a törvényjavaslat leszögezte, hogy „az egyes országrészek elnevezései az egyes nemzetiségek számára politikai jogokat se nem alapitanak, se nem adnak”. A román nemzetnek csak egy, a szimbólumhasználatra vonatkozó jogát deklarálja a törvénycikk, előírva a román nemzeti jelvény felvételét a nagyfejedelemség címerébe. ${ }^{47}$

A Lászlóffy-féle örmény törvényjavaslat szó szerint átvette a román nemzeti törvény szövegét (a címerhasználatra vonatkozó paragrafus kivételével), mindössze odatéve az örményt a már elismert négy erdélyi nemzet mellé.

A magyar országgyülés elé 1867-ben kerülő Bukovszky-féle rutén kérelem a kisebbségek által megfogalmazott tervezetek legszerényebb változatának tekinthető, amely nem tartalmazott nemzetként való elismerésről szóló deklarációt sem, egyedül a magyart említette „,szövegközben” nemzetként. A kérelem tárgyául szolgáló ruténeket „nemzetiségként”, „népfajként” írta le, sőt egy esetben a „rutének, vagyis magyar oroszok” kijelentésből arra következtethetünk, hogy a magyar politikai/államnemzet felfogást alapul véve a rutént annak egy nemzetiségeként fogta fel.

Az 1867-es kisebbségi javaslat már határozottan elveti az egy magyar(országi) nemzet elvét, 1. §-a szerint Magyarországon hat „nemzet” „ismertetik el”: a „magyar, román, szerb, szlovák, orosz [értsd: rutén] és német” mint „történeti országos népségek”. A nemzeteket már nem „köti össze” ernyőként az egy országos politikai nemzethez tartozás. Ez volt az első törvényjavaslat, amely nemzeti szempontból megtörte az ország egységét, ami a kor magyar politikusai döntő többségének számára elfogadhatatlan volt. A „nemzetiséget” a nemzet szinonimájaként (a törvényjavaslat címében is ${ }^{48}$ ) és egyben a nemzetek tulajdonságaként is használja az irat. A kollektív jogok tekintetében a kisebbségi törvényjavaslat a legbőkezübb. A szimbólumhasználat, iskola- és egyesületalapításon túl a nemzeteket megillető jogként aposztrofálja a törvényjavaslat azt is, hogy mint kollektívumok képviseltethetik magukat a főrendiházban és a végrehajtó hatalom kinevezésétől függő hivatalokban. Sajátos kollektív képviseletre utal alsóházi képviseletük, ahol szintén, mint „nemzetek képviselői” vesznek részt politikusaik az irat szerint, ám mégsem közvetlenül nemzetek delegáltjairól van szó, hiszen a mandátumok továbbra is választókerületekhez kötöttek. Képviselőik „nemzeti nyelven” szólhatnak az országgyülésen. Az anyanyelvhasználattól gyakorlatilag alig eltérő jelentés horderejét az adja, hogy anyanyelve csak egyénnek lehet, míg a „nemzeti nyelv” egy nemzet attribútumaként szerepel a

47 Ennek végrehajtására, Erdély címerének ilyen megváltoztatására nem került sor.

48 „Az országos nemzetiségeknek és nyelveknek Magyarországban leendő szabályozására és biztositására”. 
dokumentumban. A nemzeti képviselet jelleget erősítené az is, hogy a vármegyék és így a választókerületek nyelvi határok mentén való kikerekítését írja elő a törvényjavaslat, ami a nemzeti képviselet elvével együtt már közelít a területi autonómia programjához.

A kisebbségi törvényjavaslat elsőként részletezi a már egyéb törvényjavaslatokban is felbukkanó iskola- és egyesületalapítási jogot, amelyet saját „közegek” felállításával gyakorolhatnak az egyes nemzetek. Ezek megalakítása és megszervezése „nemzeti gyülések vagy nemzeti kongresszusok” feladata, amelyek adószedési joggal is rendelkeznének a nemzetükhöz tartozó állampolgárok irányában, továbbá jogukban állna a királyhoz, az országgyűléshez vagy a kormányhoz „előterjesztést, sérelmeket és javaslatokat" benyújtani.

Az 1867-es albizottsági törvényjavaslaton a nemzetiségi bizottság egésze csak kevés, nyelvhasználati rendelkezésekre vonatkozó változtatást hajtott végre, így annak külön vizsgálata nem indokolt. A törvényjavaslat az 1860-as évek hasonló tervezetei között azáltal foglal el speciális helyet, hogy nem tartalmaz nemzetként való elismerést, nemzeti deklarációkat, még a magyar politikai nemzetet illetően sem. Eötvös feltehetőleg óvatosságból kerülte egyáltalában a „nemzet” szó használatát is, ami csak látszólag jelenti az állásfoglalás hiányát: a tárgykör nem érintésével a bizottság a korabeli status quót hagyja meg. A törvényjavaslat így jogalanyként csak állampolgárokat ismert, a már konszenzusos elemnek tekinthető egyesület- és iskolaalapítási jogot is az általános társulási jog körében tárgyalta, amely az egyéneknek „eddig is... ezentúl is jogában állott”. A „nemzetiség” szót az egyén tulajdonságaként használja a javaslat, amely attribútum így átvihető a társulásokra is, amelyek „nemzetiségi törvényes igényeket” is szolgálhatnak. A javaslat ${ }^{49}$ egy alkalommal, a közigazgatási hivatalnokok kiválasztásának szabályozásakor azonban említ „nemzetiségeket” főnévként is.

Deák Ferenc törvényjavaslatának a részletes vita során történt módosításai a nemzetre vonatkozó deklarációt és a nemzetiségi csoportok közösségként való kezelésének tárgykörét nem érintették, így a Deák-féle javaslatot és a nemzetiségi törvényt egységesen vizsgálhatjuk. Preambulumában deklarálja az „oszthatatlan egységes magyar nemzet” elvét, melyre a paragrafusokra osztott részek közül még az államnyelvre vonatkozónál is hivatkozik. A tétel deklaratív jellege „az alkotmány alapelvei szerint is” fordulattal jelzi, hogy megtartani és nem létrehozni kívánja az egységes magyar politikai nemzetet. A Deák-féle magyar politikai nemzet minden állampolgárból áll, az egyén és az államnemzet között tehát nincs átmeneti kategória. A törvénycikk azonban más ponton kollektívumként említ „nemzetiségeket” (azok felsorolása nélkül), azokat is létezőként elismerve. Az 1. § ugyanakkor ki nem mondva utal arra, hogy a nemzetiségeket nyelveik különböztetik meg egymástól, és a magyar is egy a nemzetiségek közül. ${ }^{50}$

A nemzetiségi csoportok jogalanyisággal a Deák-féle törvényjavaslat szerint alig rendelkeztek. Egységként csak a közigazgatási hivatalok betöltésénél hivatkozik

49 „A nemzetiségi egyenjogúságról”.

50 „A törvények magyar nyelven alkottatnak, de az országban lakó minden más nemzetiség nyelvén is...”. A paragrafus egészében a „magyar” csak mint nyelv szerepel, ám a „minden más nemzetiség” csak akkor nyer értelmet a mondatban, ha a magyart is nemzetiségnek tekinti a szöveg, amely hordozza a magyar nyelvet (ami „mellesleg” az államnyelv is a szakasz szerint). 
„nemzetiségekre” a javaslat, ${ }^{51}$ és a nyelveiken való törvénykiadás elöírásának tárgyában tekint a törvénycikk kollektívumként a nemzetiségi csoportokra. Az iskola- és a művelődési intézetek alapításának joga kifejezetten „egyes honpolgárok” jogosultságaként szerepel a törvényben, szintén az érvényben lévő szabályozások megtartásaként. Miután a „nemzetiség” a törvénycikkben is többnyire az egyén ismérveként jelenik meg, ilyen „nemzetiségi” sajátossága, „igénye” a társulatoknak, egyesületeknek is lehet. A törvény(javaslat) az állam kötelességévé tette, hogy gondoskodjon az állampolgárok anyanyelvi oktatásáról - bár az oktatás nem csak állami feladat volt. Deák törvényjavaslatának volt még egy sarkalatos pontja: területtel bíró politikai nemzetnek ismerte el a horvát nemzetet, arra szintén mint meglévőre hivatkozva, az utolsó paragrafus ugyanis megállapítja, hogy Horvát-Szlavónországra nem terjed ki a nemzetiségi törvény. ${ }^{52}$

A már a nemzetiségi törvényjavaslat hatálybalépése után született 1870-es függetlenségi-nemzetiségi „nemzetiségi törvény” az első olyan (részben) magyar javaslattervezetnek tekinthető, amely mind a hat nemzetiségi csoportot (köztük a magyart) nemzetnek ismerte el. A javaslat ezen hat nemzet összességére nem tételezett politikai nemzetet, csak „össznevezetet”, ami „magyarországi [nép] (peuple hongrois)”, hogy mintegy az államközi színtéren is megnevezhesse az állampolgárok összességét, „nehogy a magyar (magyare) nemzetiség ebböl különös hasznot vonhasson le vagy befolyást vezethessen $l e ”$. A nemzeteket emellett „nemzetiségnek” és „népfajnak” is nevezi a dokumentum. Ezen nemzetek kollektív jogait ez a dokumentum is az iskola- és tudományos vagy mủvelődési egyesületek alapításában határozza meg. Az országgyủlésben az 1867-es kisebbségi javaslathoz hasonlóan „nemzetiségek képviselőiről” szól, a törvények hat nyelven való kihirdetése mellett.

Pauliny törvényjavaslata „a nemzetiségek egyenjogúvá tételéről” tartalmazza a magyar politikai nemzet tételét, amely „a következő genetikus nemzetekből áll: magyarokból, románokból, szlovákokból, szerbekből, ruszinokból és németekből”. Ez a megfogalmazás a Vlad-Popoviciu-féle javaslatra emlékeztet azzal a különbséggel, hogy a politikai nemzetet „magyar” jelzővel látja el, így egyszerre jelenik meg a magyar nemzetként és (a korabeli felfogás szerinti) nemzetiségként, akár az 1861-es nemzetiségi bizottmányi javaslatban.

51 „.... különböző nemzetiségekből a szükséges nyelvekben tökéletesen jártas s másként is alkalmas személyek a lehetőségig alkalmaztassanak.”

52 A horvát nemzettel kapcsolatban ugyanezen paragrafus leírja, hogy a horvát-magyar „egyezmény” alapján a sabor képviselői anyanyelvükön is szólhatnak a „magyar-horvát országgyűlésen” (megkülönböztetve az 1. §-ban említett „magyar országgyűléstől”, melynek nyelve a magyar), amely törvényhely látszólag fölösleges, hiszen egy másik törvényre hivatkozik, azt ráadásul félreértelmezve, ugyanis az egyezményt becikkelyező 1868. évi XXX. törvénycikk csak a horvát nyelv használatát engedi a sabor képviselőinek. A különbség relevanciája a nagyszámú horvát-szlavónországi szerb kisebbség szempontjából volt, és bár a két nyelv beszélt változatban azonos, a „horvát nyelvet is használhatják” fordulat az írásbeliséget illetően rendelkezett relevanciával, ugyanis a horvát képviselők felszólalását a Képviselőházi napló hasábosan horvát és magyar nyelven rögzítette. Képviselőház, CCCXXIII. ülés, 1868. 11. 24. Képviselőházi napló, 1865, XI. kötet, 4.; CIEGER András: Horvát képviselők a magyar országgyülésben (1868-1918) = A magyar-horvát együttélés fordulópontjai: intézmények, társadalom, gazdaság, kultúra / Prekretnice u suživotu hrvata i mađara - Ustanove, društvo, gospodarstvo i kultúra, szerk. TuRKALJ Jasna, KARBIć Damir, Horvát Történettudományi Intézet - MTA BTK Történettudományi Intézet, Budapest, 2016, 426-435. 
Nemzetek vagy nemzetiségek? Törvények és törvénytervezetek a nemzetiségi egyenjogúságról...

Kollektív jogokat ezen „genetikus nemzeteknek” nem határoz meg, a törvényhatóságok „nemzetiségi” alapú kikerekítését azonban rendelkezései közé veszi.

\section{7. Összefoglalás}

A törvények és törvényjavaslatok egyes rendelkezéseinek ismerete után tárulhat elénk egyes rendelkezések egyik törvényjavaslatból egy másikba történő átvétele, s nyomon követhetjük azok eredetét, sőt az összevetés nyomán a nemzetiségcsoportok jogai bővítésének vagy szűkítésének tendenciáit is megfigyelhetjük. Világosan kirajzolódik emellett az 1860-as évek nem magyar és magyar álláspontja a kérdésben, így megismerhetjük azt is, hogy milyen szabályozási tárgyakban volt egyetértés vagy eltérés magyar és román, szerb stb. politikusok között, s melyeket sikerült áthidalni, azaz az álláspontok esetleges közeledését is tetten érhetjük.

Az egész magyarországi lakosságot átfogó politikai nemzet tételében nem mutatkozik a tervezetekben konszenzus. A magyar ${ }^{53}$ törvényjavaslatok közül az 1861-es nemzetiségi bizottmányi, az 1863-as helytartótanácsi bizottmányi és a Deák-féle törvényjavaslat (így a törvénycikk) deklarálta annak létét, azt „magyar” jelzővel ellátva. Bár hallgat erről, mégis idesorolható az 1867-es (al)bizottsági törvényjavaslat és a nem magyar nemzetiségi csoportok részéről a Bukovszky-féle kérelem is. Az államnemzeti felfogás rendi, majd 1848-ban nyugat-európai minták által meghatározott alapokon nyugodott, a magyar politikai nemzet szabályozása nem a törvényjavaslatok készítőinek „találmánya” volt. Új elemet legfeljebb az „egységes és oszthatatlan magyar nemzet” kifejezés 1861-es nemzetiségi bizottmányi megformálása, majd e kifejezésnek a helytartótanácsi bizottmány és a Deák-féle törvényjavaslat, így a törvénycikk általi átvétele mutat. A nem magyar nemzetiségi csoportok részéről a Vlad-Popoviciu-féle és az 1870-es Pauliny-féle törvényjavaslatok elismerték az ország nemzeti egységét, ám a „magyar” jelzőt Vlad-Popoviciu kifejezetten „magyarországi”-ra cserélte.

Ezen politikai nemzet egyes állampolgárokból áll az 1861-es nemzetiségi bizottmány és a Deák-féle törvényjavaslat szerint, míg a helytartótanácsi bizottmány javaslatának preambuluma ezt a keresztény állampolgárokra szűkíti. A Vlad-Popoviciu-féle törvényjavaslat, a hosszabb helytartótanácsi bizottmányi javaslat és Pauliny Tóth tervezete szerint viszont az államnemzet nem több millió, hanem hat alkotóelemből áll: a felsorolt genetikus nemzetekből, illetve (a helytartótanácsi bizottmány javaslata szerint) nemzetiségekből. Pauliny felfogásában egyértelműen a Vlad-Popoviciu-törvényjavaslat hatása tükröződik.

Az 1861-es karlócai és turócszentmártoni határozatok, az 1867-es kisebbségi és az 1870-es függetlenségi-nemzetiségi törvényjavaslatok nem ismertek el az egész lakosságra kiterjedő államnemzetet, hat megnevezett nemzetre osztották az államot. A nemzetként való elismerést továbbá az 1861-es Vlad-Popoviciu-féle javaslat a „magyarországi”,

53 Ide számolván az 1861-es nemzetiségi bizottmányi törvényjavaslatot, annak ellenére, hogy létrehozásában nem magyar képviselők is részt vettek, de nem ide véve az 1870-es függetlenségi-nemzetiségi programot. 
míg az 1870-es Pauliny Tóth-féle a „magyar” politikai nemzeten belül valósította meg. ${ }^{54}$ A nemzetiségi csoportok nemzetként való elismerése és az egy politikai nemzet tétele tehát nem zárta ki egymást két nem magyar (1861, 1870: Pauliny Tóth) programban, míg az 1867-es kisebbségi és 1870-es függetlenségi-nemzetiségi javaslatokban a hat nemzet nem alkotott összességet. Arató Endre megállapítása szerint azonban ez azt vetette volna fel a magyar politikusok félelmeiben, hogy nincs különbség a magyarországi szerb és román nemzet, illetve Szerbia és Románia nemzetei között. ${ }^{55}$ A nemzetként való elismerést a horvátokén túl magyar részről csak az 1870-es függetlenségi-nemzetiségi programban találjuk.

A Magyarországon élő nem magyar nemzetiségi csoportok nemzetiségekként való elismerését azonban mindegyik vizsgált tervezet és a nemzetiségi törvénycikk is tartalmazta, abban azonban különböztek, hogy milyen jogokat rendeltek hozzá ezen kollektívumokhoz. ${ }^{56}$ Legnagyobb összhang az iskolák és művelődési egyesületek alapítási jogát illetően alakult ki, melyet kifejezetten hozzárendel a nemzet(iség)ekhez az 1861-es karlócai határozat, a Vlad-Popoviciu-féle törvényjavaslat, a nemzetiségi és helytartótanácsi bizottmányok javaslatai, az 1867-es kisebbségi és az 1870-es függetlenségi-nemzetiségi törvényjavaslat is. 1867-re ez közösséget megillető jogként kikerült a magyar tervezetekből, de bekerült a nemzetiségi törvénybe (a nemzetiségi bizottsági és a Deák-féle törvényjavaslatok nyomán) az egyének és egyházak egyébként is fennálló iskola- és egyesületalapítási joga.

Néhány nemzetiségi tervezet valamilyen formájú kollektív nemzeti képviseletet is körvonalazott a képviselőházban: az 1861-es karlócai határozat kifejezetten vajdasági delegáltak révén vélte azt megvalósíthatónak, az 1867-es Bukovszky-féle kérelem elsősorban választójogi természetű volt, így külön rutén képviseletet említett, az 1867-es kisebbségi törvényjavaslat pedig „nemzetek képviselőiről” szól, amit a választókerületek nyelvek szerinti kikerekítésén keresztül célzott elérni. Ez utóbbi a főrendiházban már testületi nemzeti érdekképviseletről szól, a „megfelelő” képviseltetésen túl konkrét számot vagy kvótát nem ír elő. A végrehajtó hatalom kinevezésétől függő közigazgatási hivatalokba hasonló „megfelelő képviseletről” rendelkezik a kisebbségi javaslat, amit az 1867-es bizottsági, így Deák-féle törvényjavaslat, majd törvénycikk is átvett, a kötelezettséget azonban „lehetőségig”-re szelídítve.

A félig laikus képviselőkből álló ortodox egyházi gyűlések formájában a szerb nemzetiség számára már kivívott jogosultság volt uralkodói engedélyhez kötve a nemzetiségi kongresszus tartása, ám az 1867-es kisebbségi javaslat országos rendszerré szervezte volna a teljesen nemzeti, világi jelleggel felruházott nemzeti kongresszusokat (köztük a magyart), amelyek közhatalmi jogosultságot is kaptak volna a már említett adókivetés formájában. A kongresszusok feladata a művelődés és a „közjóllét” előmozdítása és segélyezése lett volna, mindenekelőtt saját oktatási intézmények létrehozása és müködtetése.

54 Az erdélyi román nemzeti törvénycikk (az örmény törvényjavaslattal együtt) 4, (illetve 5) nemzetre osztotta Erdélyt, ami az unióval jelentőségét vesztette, így azokat nem értékelhetjük a magyarországi politikai nemzet szempontjából.

55 ARATó: $i . m ., 448$.

56 Az 1867-es albizottsági javaslat ugyanakkor csak a hivatalok viselésénél hivatkozik rájuk mint közösségekre. 
Ezeket nem az államtól vállalták volna át, hiszen az oktatás a korszakban csak felső- és részben középszinten volt elsősorban az állam feladata. A kisebbségi javaslat ezen tétele szerb és román részről már 1868 tavaszára-nyarára teljesült a (már meglévő) szerb és román „,nemzeti egyházi gyülekezetek”, „kongresszusok” megtartását lehetővé tévo 1868. évi IX. törvénycikk révén, így az 1868. évi IX. törvénycikkbe „román nemzeti egyházi gyülekezet (congressus)" került végül.57

A törvények minden nemzetiség nyelvén való kihirdetése olyan közös alapnak bizonyult, amelyet a magyar politikai elit is magától értetődő kiindulópontnak tekintett ekkoriban. Elsőként a Vlad-Popoviciu-törvényjavaslat említette ezt, amelyet azután minden magyar és nemzetiségi tervezet átvett, ${ }^{58}$ egyedüliként az 1867-es nemzetiségi albizottság hagyta el az országgyủlésre vonatkozó szabályozásokkal együtt. A közben (1868 áprilisában) napirendre kerülő, a törvények kihirdetéséről szóló törvényjavaslat kormány általi beterjesztésében még nem szereplő kitétel az 1867-es kisebbségi javaslat egyik aláírója, Sigismund Pop javaslatára került bele a kihirdetési törvényjavaslatba, ami a Ház és a király egyetértésével találkozott. ${ }^{59}$ Így annak már nem volt tétje, hogy ezt a rendelkezést a nemzetiségi bizottság kihagyta törvényjavaslatából, hogy majd Deák Ferenc „tegye vissza” azt. A nemzetiségi törvénybe is bekerülő kitétel így a nem magyar nemzeti mozgalmak által az 1860-as években elért vívmányok egyikének tekinthető. Az 1870-es függetlenségi-nemzetiségi javaslat ebben a tekintetben már nyitott kapukat döngetett.

Az ország területi egységét megbontó autonóm nemzeti közigazgatási terület követeléséig csak az 1861-es karlócai kongresszus (az 1849-1860-as Szerb Vajdaság és Temesi Bánságnál kisebb területen) és a turócszentmártoni gyűlés ment el. Az országgyủlés előtt a vármegyék nemzetiségi alapú kikerekítésére „gyengített” kvázi területi kérelmek a nemzetiségi csoportok közigazgatásbeli elhatárolását szolgálták, ami természetesen csak a nem magyar tervezetekben jelent meg: a Vlad-Popoviciu-féle törvényjavaslat ezen rendelkezését az 1867-es kisebbségi és az 1870-es Pauliny Tóth-féle törvényjavaslat is átvette.

A nemzetek külső kollektív megjelenítését elősegítő szimbólumhasználat jogát a magyarországi törvényjavaslatok közül csak az 1867-es kisebbségi javaslat (nemzeti zászlóhasználat jogát) és az erdélyi román nemzeti törvény tartalmazta az 1861-es szerb, illetve szlovák autonóm területről szóló határozatokon túl.

57 1868. évi IX. törvénycikk a görög-keleti vallásúak ügyében. MÁRkus: i. m., 377-378. A „román egyházi kongresszus" elnevezésével kapcsolatban kialakult disputában az eredetileg csak a szerb kongresszusnál alkalmazott „nemzeti” jelzőt Eötvös javaslatára fogadta el csekély többséggel a Ház. Az Eötvössel vitázó Bánó Miklós képviselő a szerbeket illetően elismerte, hogy nekik a nemzeti jelző használatára egyházi kongresszusuk tekintetében „már historiai joguk” van. Képviselőház, CCXXVI. ülés, 1868. 05. 08, Képviselőházi napló, 1865, VII. kötet, 205-206.

58 A Bukovszky-féle kérelem kivételével. Az erdélyi román nemzeti törvénynek erre külön nem kellett kitérnie, miután már az azt elfogadó országgyűlés is három nyelven működött, az örmény törvényjavaslatnak pedig nem volt nyelvi relevanciája.

59 Törvényjavaslat a törvények kihirdetéséről, 1868. 03. 24, Képviselőházi irományok, 1865, IV. kötet, 193. sz., 3-4. Képviselőház, CCXVI. ülés, 1868. 04. 18, Képviselőházi napló, 1865, VII. kötet, 99-100. A többnyelvü törvénykihirdetésről a nemzetiségi törvénycikk után l. ANDRÁsSY György: Hány hivatalos nyelve volt Magyarországnak az 1868. évi XLIV. tc. szerint?, Jogtörténeti Szemle, 2017/3, 4-11. 
Feltehetően a kor politikusai sem gondolták, hogy fél évszázadra alkotnak későbbi módosítás nélküli törvényt. ${ }^{60}$ Áthidaló, magyar és nem magyar politikusok által egyaránt elfogadott megoldás a nemzetként való elismerés kérdésében nem született. A nem magyar nemzeti mozgalmak számára ez elengedhetetlen alapfeltétellé vált, míg a magyar álláspont nem engedett az egy magyar politikai nemzet tételéből, ráadásul magyar részről 1863 után a nemzetiségi csoportok felsorolását (azaz a magyart a többivel egy szintre helyezését) elhagyó tendencia éppen az álláspontok távolodását mutatja. Ez feltehetőleg nem volt független az osztrák-magyar közjogi-politikai helyzet változásától és a magyar önállóság növekedésétől. Magyar részről a nem magyar nemzeti mozgalmak tervezeteiből való átvételre csak a baloldali ellenzék részéről került sor 1867 után a vizsgált korszakban. Amennyiben az 1870-es függetlenségi-nemzetiségi álláspontot közösnek tekintjük, megállapíthatjuk, hogy 1867-hez képest a szimbólumhasználatot, a megyék kikerekítését és az országgyüléshez kötött jogok tekintetében a nem magyar nemzeti mozgalmak engedtek követeléseikből az egy politikai nemzet elvének elvetése és helyébe hat magyarországi nemzet elismeréséért cserébe. A kormánypárti magyar politikai vezetés és a nem magyar nemzeti mozgalmak álláspontja között közös elemet a törvények többnyelvü kihirdetése és az iskola- s egyesületalapítási jog, valamint román és szerb egyházi-nemzeti kongresszus biztosításán túl nem találunk a kollektív jogosultságokat illetően. A legfontosabb kérdésekben tehát a magyar álláspont érvényesült, azonban a tervezetek és a nemzetiségi törvénycikk egyben nyelvtörvények (törvényjavaslatok) is voltak, ahol már jóval több „szelepen” keresztül lehetett a nem magyar igényeknek legalább részben megfelelő politikát folytatni, s nagyobb tér nyílt esetleges közös álláspont kialakítására is, hozzátéve, hogy a nyelvi szabályozások zöménél már a vármegyei municipalista elit hadállásaival is számolnia kellett a döntéshozóknak. A nemzetiségi törvény és tervezetei nyelvhasználatot érintő rendelkezéseinek összevetésével teljes körü képet kaphatunk arról, hogy a magyar és nem magyar politikusok végül miben találták meg az összhangot, és mely pontok voltak alkalmasak arra, hogy a feszültség magvát - most már tudjuk: újabb ötven évre - elhintsék.

\section{Irodalomjegyzék}

1. ANDRÁssy György: Hány hivatalos nyelve volt Magyarországnak az 1868. évi XLIV. tc. szerint?, Jogtörténeti Szemle, 2017/3.

2. Arató Endre: A magyar politikai nemzet fogalmának vitája az 1860-as évek országgyülése, Történelmi Szemle, 13/1.

3. Berzeviczy Albert: Az abszolutizmus kora Magyarországon: 1849-1865, 3. k., Franklin Társulat, Budapest, 1922.

4. CIEGER András: Horvát képviselők a magyar országgyülésben (1868-1918) = A magyar-horvát együttélés fordulópontjai: intézmények, társadalom, gazdaság, kultúra / Prekretnice u

60 A nemzetiségi törvény továbbéléséről ld: MıKó: i. m., III-V. fejezetek.; SzaLAYNÉ SÁndor Erzsébet: A kisebbségvédelem nemzetközi jogi intézményrendszere a 20. században, Gondolat, Budapest, 2003; NAGY Noémi: A hatalom nyelve - a nyelv hatalma: Nyelvijog és nyelvpolitika Európa történetében, Dialóg Campus, Budapest, 2019, 171-199. 
suživotu hrvata i mađara - Ustanove, društvo, gospodarstvo i kultúra, szerk. TuRKALJ Jasna, KARBÍ́ Damir, Horvát Történettudományi Intézet - MTA BTK Történettudományi Intézet, Budapest, 2016.

5. CSERnus-LukÁcs Szilveszter: A nemzetiségi és nyelvi kérdés szabályozása Magyarországon és Erdélyben az októberi diplomától a nemzetiségi törvényig = Nemzetiségi-nyelvi szuverenitás a hosszú 19. században, szerk. NAGY Noémi, Gondolat, Budapest, 2020.

6. CsERnus-LukÁcs Szilveszter: Felírási javaslat a nemzetiségi egyenjogúság tárgyában, Századok, 2017/1.

7. CSernus-LukÁcs Szilveszter: Utak a nemzetiségi törvénycikkig, Tavaszi Szél konferencia konferenciakötete, Doktoranduszok Országos Szövetsége, Budapest, 2016.

8. DЕÁK Ágnes: „Nemzeti egyenjogúsítás”. Kormányzati nemzetiségpolitika Magyarországon 1849-1860, Osiris Kiadó, Budapest, 2000.

9. Deák Ágnes: Az 1868-as nemzetiségi törvény ausztriai elözményei, Magyar Kisebbség, 2009/1-2.

10. DeÁK Ágnes: Soknemzetiségü nemzetállam és soknemzetiségü birodalom erőterében - Nemzetiségpolitikai alternatívák 1868 előtt, Századvég, 2008/4.

11. Demeter M. Attila: Politikai nemzet versus nemzetiség - 1848, 1861, 1868 = Nemzet, faj, kultúra. A hosszú 19. században Magyarországon és Európában, szerk. HöRcher Ferenc, LAJTAI László, Mester Béla, MTA BTK Történettudományi Intézet, Budapest, 2016.

12. Grosschmid Gábor: A szerb vajdaság (1849-1860) = Bács-Bodrog vármegye egyetemes monográfiája. I. kötet, szerk. Dudás Gyula, Bács-Bodrog vm. közönsége, Zombor, 1896.

13. KемÉNy G. Gábor: Iratok a nemzetiségi kérdés történetéhez Magyarországon a dualizmus korában, I. kötet 1867-1892, Tankönyvkiadó, Budapest, 1952.

14. MALFÉR, Stefan: „Empfangen, nicht verstanden”(Überlegungen zur Nationalitätenfrage und zu einem Nationalitätengesetz für Ungarn in der Zeit des Provisoriums) = Polgárosodás Közép-Európában - Verbürgerlichung in Mitteleuropa, szerk. Sомоgy Éva, Budapest, 1991.

15. MÁRkus Dezső (szerk.): Magyar Törvénytár 1000-1890. 1836-1868. évi törvényczikkek - Corpus Juris Hungarici, VIII. kötet, Franklin Társulat, Budapest, 1896.

16. Mester Miklós: Az autonóm Erdély és a román nemzetiségi követelések az 1863-64. évi nagyszebeni országgyülésen, Dunántúl Pécsi Egyetemi Könyvkiadó, Budapest, 1936.

17. Mıкó Imre: Nemzetiségi jog és nemzetiségi politika, Minerva, Kolozsvár, 1944.

18. NAGy Noémi: A hatalom nyelve - a nyelv hatalma: Nyelvi jog és nyelvpolitika Európa történetében, Dialóg Campus, Budapest, 2019.

19. PÉTER László: Az 1868:XLIV. tc. „a nemzetiségi egyenjogúság tárgyában”és a törvényhatóság hivatalos nyelve = Az Elbától keletre, szerk. PÉTER László, Osiris Kiadó, Budapest, 1998.

20. Schletт István: A nemzetiségi törvényjavaslat országgyülési vitája 1868, TTFK - Kortárs Kiadó, 2002.

21. Sipos Levente (szerk.): A magyar állam és a nemzetiségek. A magyarországi nemzetiségi kérdés történetének jogforrásai 1848-1993, Napvilág Kiadó, Budapest, 2002.

22. SZALAYNé SÁNDOR Erzsébet: A kisebbségvédelem nemzetközijogi intézményrendszere a 20. században, Gondolat, Budapest, 2003.

23. SzÁsz Zoltán (szerk.): Erdély története három kötetben, Akadémiai Kiadó, Budapest, 1986. 


\section{Források}

1. Az 1861-ik év april. 2-án Pesten egybegyült országgyülés képviselőházának naplója, Pest, 1861, II. kötet, https://library.hungaricana.hu/hu/view/OGYK_KN-1861_02/?pg=0\&layout=s (letöltés ideje: 2020. 04. 20.) [Képviselőházi napló, Pest, 1861. II. k.].

2. Az 1863. évjúlius 1-re Nagy-Szebenbe egybehívott erdélyi országgyülés irományai. Nagyszeben, 1864, https://library.hungaricana.hu/hu/view/Orszaggyules_ErdelyiOrszaggy Dok_18621864_ Iromanyok/?pg=0\&layout=s (letöltés ideje: 2020.02 .10 .)

3. Az 1865-dikévi deczember 10-dikére hirdetett országgyülés képviselőházának irományai, Pest, 1868, IV. kötet, https://library.hungaricana.hu/hu/view/OGYK_KI-1865_04/?pg=0\&layout=s (letöltés ideje: 2018. 03. 20.) [Képviselőházi irományok, Pest, 1865., IV. k.].

4. Az 1865-dik évi deczember 10-dikére hirdetett országgyülés nyomtatványai-Képviselőház-irományok, Pest, 1867, II. kötet, https://library.hungaricana.hu/hu/view/OGYK_KI-1865_02/?p$\mathrm{g}=0$ \&layout=s (letöltés ideje: 2020. 03. 20.) [Képviselőházi irományok, Pest, 1865, II. k.].

5. Az 1865-dik évi deczember 10-dikére hirdetett országgyülés nyomtatványai-Képviselőház - irományok, Pest, 1868, VI. kötet, https://library.hungaricana.hu/hu/view/OGYK_KI-1865_06/?p$\mathrm{g}=0 \&$ layout=s (letöltés ideje: 2020. 03. 20.) [Képviselőházi irományok, Pest, 1865., VI. k.].

6. Az 1865-dik évi deczember 10-dikére hirdetett országgyülés nyomtatványai - Képviselőház - irományok, Pest, 1868, VII. kötet, https://library.hungaricana.hu/hu/view/OGYK_KI-1865_07/?p$\mathrm{g}=0 \&$ layout=s (letöltés ideje: 2020. 03. 20.) [Képviselőházi irományok, Pest, 1865., VII. k.].

7. Az 1865-dik évi deczember 10-dikére hirdetett országgyülés nyomtatványai - Képviselőház - napló, Pest, 1866, I. kötet, https://library.hungaricana.hu/hu/view/OGYK_KN-1865_01/?p$\mathrm{g}=0 \&$ layout=st (letöltés ideje: 2020. 03. 30.) [Képviselőházi napló, Pest, 1865. I. k.].

8. Az 1865-dik évi deczember 10-dikére hirdetett országgyülés nyomtatványai - Képviselőház - napló, Pest, 1866, II. kötet, https://library.hungaricana.hu/hu/view/OGYK_KN-1865_02/?pg=0\&layout=s (letöltés ideje: 2020. 03. 20.) [Képviselőházi napló, Pest, 1865. II. k.].

9. Az 1865-dik évi deczember 10-dikére hirdetett országgyülés nyomtatványai - Képviselőház - napló, Pest, 1867, III. kötet, https://library.hungaricana.hu/hu/view/OGYK_KN-1865_03/?p$\mathrm{g}=0$ \&layout=s (letöltés ideje: 2020 . 03. 30.) [Képviselőházi napló, Pest, 1865. III. k.].

10. Az 1865-dik évi deczember 10-dikére hirdetett országgyülés nyomtatványai-Képviselőház-napló, Pest, 1867, IV. kötet, https://library.hungaricana.hu/hu/view/OGYK_KN-1865_04/?pg=0\&layout=s (letöltés ideje: 2020. 03. 04.) [Képviselőházi napló, Pest, 1865. IV. k.].

11. Az 1865-dik évi deczember 10-dikére hirdetett országgyülés nyomtatványai-Képviselőház-napló, Pest, 1868, VII. kötet, https://library.hungaricana.hu/hu/view/OGYK_KN-1865_07/?pg=0\&layout=s (letöltés ideje: 2020. 03. 30.) [Képviselőházi napló, Pest, 1865. VII. k.].

12. Az 1865-dik évi deczember 10-dikére hirdetett országgyülés nyomtatványai-Képviselőház-napló, Pest, 1868, IX. kötet, https://library.hungaricana.hu/hu/view/OGYK_KN-1865_09/?p$\mathrm{g}=0 \&$ layout=s (letöltés ideje: 2020. 03. 30.) [Képviselőházi napló, Pest, 1865. IX. k.].

13. Az 1865-dikévi deczember 10-dikére hirdetett országgyúlés nyomtatványai-Képviselőház-napló, Pest, 1868, XI. kötet, https://library.hungaricana.hu/hu/view/OGYK_KN-1865_11/?p$\mathrm{g}=0 \&$ layout=s (letöltés ideje: 2020. 03. 30.) [Képviselőházi napló, Pest, 1865. XI. k.].

14. Jegyzőkönyve az 1863-ik évi Sz. Jakab hó 1-ére Nagy-Szeben szabad királyi városába legfelsőbbleg egybehivott erdélyi országgyülésnek. Nagyszeben, 1864, https://library.hungaricana.hu/hu/ view/Orszaggyules_ErdelyiOrszaggyDok_18631864_Jkv/?pg=0\&layout=s (letöltés ideje: 2020. 04. 20.)

15. Képviselöházi irományok, Pest, 1861, I. kötet, https://library.hungaricana.hu/hu/view/ OGYK_ KI-1861_01/?pg=0\&layout=s (letöltés ideje: 2020. 02. 10.) 
Nemzetek vagy nemzetiségek? Törvények és törvénytervezetek a nemzetiségi egyenjogúságról...

16. Magyarországi Törvények és Rendeletek Tára, 1867, Pest, 1868, https://library. hungaricana.hu/ hu/view/OGYK_RT_1867/?pg=0\&layout=s (letöltés ideje: 2020. 03. 20.)

17. Pálffy levélfogalmazványa a fókancellárnak, 1862. 8. 19. Magyar Nemzeti Levéltár Országos Levéltár Abszolutizmus kori levéltár, D 191 M. Kir. Helytartótanács, elnöki iratok 16823. III. 1862.

\section{Levéltári források}

1. A törvényjavaslat kidolgozására összehivott bizottmány ülésének jegyzőkönyve, MNL OL D 215 II. 1863:24., 326.

2. Abonyi István m. k. helyt. tanácsos mint elöadó által szerkesztett felírási és törvényjavaslat a nemzetiségi és nyelvi jogviszonyok tárgyában, 1862. okt. 25. MNL OL Abszolutizmus kori levéltár, D 191 M. Kir. Httanács., eln. iratok 16823. III. 1862. 